8-14-2003

\title{
Environmental Justice and Information Technologies: Overcoming the Information Access Paradox in Urban Communities
}

Wendy A. Kellogg

Cleveland State University, w.kellogg@csuohio.edu

Anjali Mathur

Earth Day Coalition (Cleveland, Ohio)

Follow this and additional works at: https://engagedscholarship.csuohio.edu/urban_facpub

Part of the Environmental Policy Commons, Urban Studies Commons, and the Urban Studies and Planning Commons

How does access to this work benefit you? Let us know!

\section{Publisher's Statement}

(c) 2003 Wiley-Blackwell

\section{Original Citation}

Kellogg, W. A. and Mathur, A. (2003), Environmental Justice and Information Technologies: Overcoming the Information-Access Paradox in Urban Communities. Public Administration Review, 63: 573-585. doi: $10.1111 / 1540-6210.00321$

\section{Repository Citation}

Kellogg, Wendy A. and Mathur, Anjali, "Environmental Justice and Information Technologies: Overcoming the Information Access Paradox in Urban Communities" (2003). All Maxine Goodman Levin School of Urban Affairs Publications. 0123851.

https://engagedscholarship.csuohio.edu/urban_facpub/851

This Article is brought to you for free and open access by the Maxine Goodman Levin School of Urban Affairs at EngagedScholarship@CSU. It has been accepted for inclusion in All Maxine Goodman Levin School of Urban Affairs Publications by an authorized administrator of EngagedScholarship@CSU. For more information, please contact library.es@csuohio.edu. 


\title{
ENVIRONMENTAL JUSTICE AND INFORMATION TECHNOLOGIES: OVERCOMING THE INFORMATION-ACCESS PARADOX IN URBAN COMMUNITIES
}

\author{
Wendy Kellogg, Cleveland State University \\ Anjali Mathur, Earth Day Coalition
}

This article was originally published in:

Kellogg, W., \& Mathur, A. (2004). Environmental justice and information technologies: Overcoming the information-access paradox in urban communities. Sage Public Administration Abstracts, 31, 3.

Post-print standardized by MSL Academic Endeavors, the imprint of the Michael Schwartz Library at Cleveland State University, 2012

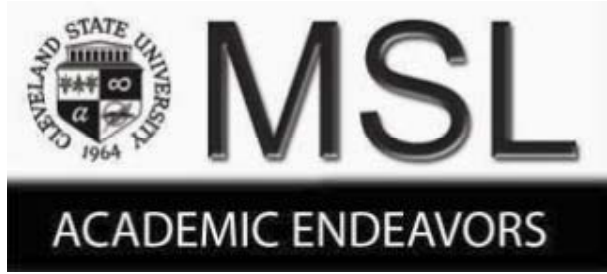




\title{
ENVIRONMENTAL JUSTICE AND INFORMATION TECHNOLOGIES: OVERCOMING THE INFORMATION-ACCESS PARADOX IN URBAN COMMUNITIES
}

\author{
WENDY KELLOGG, Cleveland State University \\ ANJALI MATHUR, Earth Day Coalition
}

\begin{abstract}
Scientific studies and resident testimony suggest that urban residents in low-income and minority communities have been subject to an unequal burden of environmental pollution and inequitable environmental enforcement practices. A key component of the equitable development and implementation of environmental policies is the participation of citizens and community-based organizations in the policy process. Such participation rests upon equitable access to agency-generated environmental information and effective use of that information by citizens. This article focuses on the adoption of Internet technologies by environmental agencies as a mechanism for disseminating information and the implications for low-income and minority residents in urban communities. A framework is developed to guide a programmatic response to overcome these implications. The results from several community-based projects are described and analyzed for their capacitybuilding effectiveness. Analysis of the projects indicates improvement in community capacity for information access and use, which bolstered community participation in the environmental decision-making process.
\end{abstract}

\section{Citizen Participation in Environmental Policy}

In their efforts to influence policy development and implementation, citizens seek enhanced knowledge about environmental conditions in their communities (NAPA 2001). Three aspects of environmental knowledge are key to democratic participation. Access to information about environmental conditions and the administrative decisionmaking processes that affect them is a prerequisite to effective political participation in environmental policy matters (Desario and Langton 1987; Kellogg 1998). The level and kind of access is a function of both the dissemination practices of the environmental agency and the skill level of the citizenry. Second, citizens and their communitybased organizations must know how to use information effectively (Sawicki and Craig 1996) in public processes for improving envirommental conditions. Finally, citizens may generate or develop information that can allow them to bring their own perspectives and rationality to the regulatory process (Heiman 1997; Susskind and Cruikshank 1987; Fischer 1990).

While the information aspects of citizen participation in regulatory decision making is neither new nor unique to

Wendy A. Kellogg is an associate professor of urban planning and environmental studies at the Levin College of Urban Affairs, Cleveland State University. Dr: Kellogg received a doctorate in city and regional planning from Cornell University. Her research focuses on the role of citizens, community organizations, and locol governments in environmental olonning and policy. She currently is a research fellow at the EPA Environmental Finance Center at Cleveland Stote University. Email; wendy@ unban, csuohio.edu.

Anjali Mathur is the project director for the Sustoinable Cleveland Partnership, a program of the Earth Day Coalition in Cleveland, Ohio. Ms. Mathur received a master's degree in environmental studies from Yale University in 1995. She works on a variety of environmental and public health issues through both local and national programs. Email: amathur@ earthdaycoalition.org. 
urban, low-income, minority communities, when it is combined with technological change, these settings create an interesting circumstance in which democratic and technocratic ideologies play out. The focus of this article is how access to information has been shaped by the adoption of the Internet as an information-dissemination mechanism by environmental regulatory and public health agencies, and the implications of this adoption for urban environmental justice communities. The article first describes urban environmental quality issues affecting low-income and minority communities. It then discusses the current environmental justice policy response to these concerns and its relevance to information access. We present a theoretical framework for understanding the variables that shape information dissemination and the environmental justice implications of Internet adoption for environmental information providers. The implication of this technology on the role of citizens is discussed. We describe and assess a case study of a partnership that is responding to information-capacity needs in four low-income and minority neighborhoods and the community-based projects that have been developed under its umbrella.

\section{Urban Environmental Quality}

Environmental quality and some of the resulting human health effects have become high-priority issues in many urban neighborhoods. America's aging cities suffer from a variety of pollution problems stemming from their industrial heritage and present-day industrial productivity. In many older city neighborhoods, large and small pollutiongenerating facilities operate next door to residential areas, schools, and community institutions. Air emissions of acutely hazardous chemicals, the presence of hazardous waste generators, and proximity to hazardous waste treatment, storage, and disposal facilities are typical to many older urban neighborhoods. In addition, urban residents, like their suburban counterparts, are exposed to nitrogen and sulfur-dioxide concentrations generated by automobiles and coal-burning electric utility plants (Goldman 1991; EPA 2002).

Urban residents tend to have greater exposure to pollutants because they live closer to industrial areas, near or on contaminated land, and in degraded structures (Bullard and Wright 1992). They also tend to have lower income levels and are more likely to be African American, Hispanic or Latino, either because low income precludes the purchase or rental of housing away from contaminants, or because of historical patterns of racial and ethnic segregation. According to two studies by the United Church of Christ (1987, 1994), residents of low-income and minority communities in the United States are nearly twice as likely to live near a hazardous waste handling facility or an abandoned waste dump site than those living above the poverty line or in nonminority communities. In the face of these environmental health risks, urban residents are among those least well-equipped to mitigate environmental and health hazards because of past and current discriminatory practices, which have resulted in decreased social and personal resources (Fitzpatrick and LaGory 2000).

These environmental pollutants place stress on the health of urban residents. Residents of America's urban counties exhibit higher-than-average deaths from cardiopulmonary disease attributable to particulate air pollution (Shprentz 1996) and higher-than-average death rates from lung cancer, breast cancer, and pediatric cancers. Urban children also seem to suffer from elevated blood lead levels and asthma more often than their suburban counterparts (ATSDR 1988; Goldman 1991). Thus, urban neighborhoods, which usually do not have substantial access to political power or economic resources, tend to bear the brunt of environmental burdens (Shutkin 2000).

\section{Policy Regarding Environmental Justice and Information}

In response to the disproportionate burden of environmental contaminants faced by many poor or minority residents (GAO 1983; UCC 1987, 1994), President Clinton signed Executive Order 12898 in 1994 to establish environmental justice as a priority for the administration's envirommental policy. The executive order requires all federal agencies to examine their policies and programs to ensure they do not discriminate, intentionally or unintentionally, on the basis of race or income. In promulgating the executive order, the U.S. Environmental Protection Agency (EPA) defines environmental justice as "[t]he fair treatment and meaningful involvement of all people regardless of race, color, natural origin, or income with respect to the development, implementation and enforcement of environmental laws, regulations and policies" (EPA 1998).

The order's two components- fair treatment and meaningful involvement impose two different requirements on federal agencies. Fair treatment means that "no groups of people, including racial, ethnic or socioeconomic groups, should bear a disproportionate share of the negative environmental consequences resulting from industrial, municipal, and commercial operations or the execution of federal, state, local, and tribal programs and policies" (EPA 1998). ${ }^{1}$

The EPA's definition of environmental justice also recognizes that meaningful involvement of citizens is a prerequisite to the development of just environmental policies and administrative decisions. Many low-income and minority communities historically have been excluded from public decision-making processes, and the execu- 
tive order was intended to reverse this exclusion. The executive order specifically requires that minority and low-income communities be provided equal access to public information about human health and environmental matters (Clinton 1994; EPA 1999). However, a recent evaluation of EPA's environmental justice practices regarding permit processes conducted by the National Academy of Public Administration (2001) found that, despite its commitment to environmental justice, the agency had not adequately integrated environmental justice and community participation into its permit processes. The study also concluded that despite the EPA's efforts to disseminate environmental information, "disproportionately impacted community members want better access to technical information that will enable them to participate more effectively in negotiations about permit terms and conditions" (NAPA 2001, 4).

Such access is a key first step to participation. To the extent that citizens and their organizations can retrieve, use, and create information effectively, they can shape policy agendas and the knowledge that forms the basis of technical decisions. They can better exert their understanding of environmental risks, opportunities, and solutions in the policy process and bring their locally generated data and expertise to the policy discourse (Forester 1989; Fischer 2000).

The development of the Internet as an information technology has been significant to the availability of and access to environmental information, although its overall effect is still uncertain (Ramasubramanian 1995). Proponents argue that its potential to overcome impediments to information access will grow as information becomes more userfriendly (Naisbitt 1994). An equally likely scenario, based on past experiences with more traditional information-resource access, is that any inequality in accessing information using the Internet may lead to increased social polarization (Castells 1989). The Internet is, after all, a technological artifact that has been adopted by the core bureaucracies entrenched in what Giddens (1990) calls the "expert systems" that have come to dominate environmental conditions in the late twentieth century. In a society that is increasingly adopting a technocratic ideology (Leiss 1990), how well can people without technocratic expertise-which grants considerable power to affect decisions participate?

The adoption of information technologies such as the Internet has great implications for low-income and minority urban residents and the community-based organizations working in these neighborhoods. Long-standing inequalities in resource access (including information access) between more affluent and less affluent communities raises issues of environmental justice if the adoption of these technologies creates disproportionate access to environmental information. This poses a problem for those seeking to overcome environmental inequities, as they have been manifest in urban neighborhoods and are at the core of the problem that the project described here seeks to address.

Several questions arise from this discussion: What is the role of information in citizen participation in agency decision-making processes? What factors shape the availability of information provided by the agencies? What implications does the Internet have for access to agency information in low-income and minority communities? What skills are needed by neighborhood leaders to participate more effectively in environmental problem solving? These questions have guided development of the theoretical framework presented below.

\section{Theoretical Framework}

\section{Information and Agency Policy Development and Implementation}

Information is an input to policy formulation and decision making, and is an outcome of policy implementation. Urban residents and community-based organizations have a role in both aspects.

Input. The role of citizens in policy-formulation processes may vary and is determined by the agency's information needs and preferences and by citizens' willingness and capacity to participate. To fulfill their legal responsibility, regulatory agencies often solicit comments from citizens, traditionally during public meetings and hearings or through written correspondence. Regulatory agencies may seek information from citizens about community objectives and preferences in order to develop policies and programs that are more suitable (Forester 1989; Tauxe 1995; Kellogg 1998) or to solicit substantive or scientific information from citizens to improve the agency's decision making (Kweit and Kweit 1987) - for example, through creation of citizen advisory or stakeholder committees. Considerable evidence exists that many citizens not only understand scientific information generated by the agency, but, when provided with an appropriate opportunity, can provide additional locally generated scientific information or work with agency staff to design research and analyze data (Landre and Knuth 1993; Heiman 1997; Kellogg 1998). This enhanced participation in public policy decisions often reframes the notion of "expert" in the process. When citizens and their organizations can generate information and form their own local knowledge systems, they can begin to define an alternative rationality to frame decisions, that is, the rules, evidence, and decision-making criteria they consider most appropriate for making decisions about environmental conditions in their neighborhoods (Fischer 2000). Through such capacity, they can negotiate the rules for managing environmental conditions (Kunreuther and Slovic 1996). 
We assert, however, that such capacity rests on a working knowledge of the "instrumental rationality" embedded in the regulatory agencies that generate and control most of environmental data that can be used by citizens and their community-based organizations.

Output. Law and policy shape the output of information in the policy-implementation process, determining both the information that is generated and its relative availability to the public. Most environmental regulatory laws require facilities that discharge pollution into the air, water, or land to monitor their emissions and to report these emissions to the regulatory agency to ensure compliance with emission permits. Agency databases on pollutant emissions are, for the most part, generated this way. Environmental regulatory agencies also monitor ambient air quality with monitoring stations across the United States for a set of six national "criteria" air pollutants (sulfur dioxide, nitrogen dioxide, particulate matters, carbon monoxide, lead, and ground-level ozone). Much of the data generated by the mix of facility reporting and agency monitoring of ambient environmental conditions is available to the public. Congressional intent in passing environmental laws was to improve environmental quality and safety in communities, and a key strategy was to allow officials and citizens access to information on enforcement and implementation. Table 1 summarizes major U.S. environmental laws and the data generated through their implementation. ${ }^{2}$ Many of the databases developed through federal-level environmental regulation are available today from the EPA and other agencies on the Internet.

\section{Retrieving Information from Public Bureaucracies}

Citizens need several types of information from environmental bureaucracies to participate effectively in the public decision-making process. Citizens need to know to what information they are legally entitled. They need information about environmental conditions to judge the relative risks of environmental hazards and to prioritize their efforts. They also need information about how agency bureaucracies are structured and the administrative procedures and practices of the agency. The availability of agency resources and agency authority and mandates are essential to understanding what a particular agency is legally required to do or is authorized to do about a specific problem. Retrieving such information is done through a bureaucracy, which shapes the accessibility of the information.

Describing the delivery of services in public-welfare agencies, Lipsky (1980) suggests a framework for understanding how dissemination and access to information, as a public good, is shaped: "[T]

\section{Table 1 Selected Major Federal Environmental Laws in the United States and Data-Generation Requirements}

\section{Low}

Clean Air Act

$1970,1977,1990$

Clean Waker Act

1972,1987

Safe Drinking

Water Act 1974, 1986

Toxic Substances

Control Act 1972

Resource Conservation

Recovery Act 1976

Comprehensive Emergency

Response Compensation

and Liability Act 1980;

Superfund Amendments

and Reauthorization Act

1986

Emergency Planning

Community Right to

Know Act 1986

Pollution Prevention Act

1999

\section{Data-collection requirements}

Discharge permits and monitoring stations

National Pollution Discharge

Eliminate System permits and surface water monitoring

Monitoring and sampling of publidy owned water supply systems

EPA testing of substances and company testing of products

Manifest system cradle to grave to

track generation, use, and disposal of hazardous waste

EPA investigation of Superfund sites*

Facility reporting to the EPA; facility

reporting to Local Emergency

Planning Committees

Facility reporting to the EPA

\section{Daka produced}

Emissions and ambient air quality measurements for six pollutants

Effuent emissions and ambient

surface water quality measurements

Levels for 77 pollutants in water systems

Regulated chemicals and their estimated health effects

Facility generation, treatment,

storage, and disposal records

National Priority List**
Online access

EPA

EPA

EPA

EPA, Agency for Toxic Substances and Disease Registry

EPA, Resource Conservation Recovery information System

EPA, Comprehensive Emergency Response Compensation and Liability Information System

EPA, Environmental Defense SCORECARD; Right to Know Nelwork

EPA, Environmental Defense SCORECARD; Right to Know Nelwork

*The Superfund is a trust created from a tax on generating industries for use by the EPA to clean up hazardous waste disposal sites in emergency situations posing significant threat to human health or the environment if corporate liability has not yet been determined.

* The list of hazardous waste disposal sites that hove been deemed in need of remedial clean up by the federal government; some 35,000 sites currently exist in the United States.

*** The Toxic Release inventory is the release data for more than 600 substances that are considered toxic by the EPA. Generating facilities must account for the release into air, water, or land, transfer off-site to treament focilities, etc. for greater than 25,000 pounds per annum of these substances.

****Facilities using and storing substantial quantities of hazardous materials for production purposes must identify these substances to Lacal Emergency Planning Committees that develop resident and employee evacuation plans in the event of unintended releases. 
to the demand for free public goods. Agencies that provide public goods must and will devise ways to ration them. To ration goods or services is to establish the level or proportions of their distribution ... [S] [Srvices may be rationed by varying the total amount available, or by varying the distribution of a fixed amount" (Lipsky 1980, 213).

Lipsky concludes that "despite [the] rhetoric of the agency and the good intentions of its staff to become more client oriented, to receive more citizen input and to encourage clients to speak out" (226), in order to conserve agency and personal resources, public agencies that provide public goods and services devise ways to ration them by decreasing demand on the agency.

According to Lipsky, this rationing is accomplished in several ways: extracting a cost for the public good, devising routines, restricting access, and pervading all these-shaping the flow of information. Although public agencies can rarely charge clients directly for services, indirect monetary costs are imposed as travel or loss of work time to receive a requested service. Time can be extracted either through the time spent interacting with the bureaucracy, or in the time requirement of procedures, routines, and waiting periods. Bureaucracies develop organizational routines or procedural requirements as prerequisites to the delivery of services, such as filling out the proper forms or providing documentation. Bureaucracies may restrict delivery of their services to a specific type of client based on attributes relevant to the services, such as geographic location or the personal characteristics of the client. These costs, routines, and classifications protect the agency staff from requests for flexibility or discretionary action, provide a system for accountability, and limit demand on agency goods and services. The street-level bureaucrats who interact most directly with clients and citizens have the greatest discretion in how they enforce or don't enforce organizational routines and requirements (Lipsky 1980).

This same framework can be used to analyze the accessibility of environmental information to urban residents. Agencies that hold environmental or public health information either ration the amount of information available or vary the distribution of information according to different classes of recipients. This rationing often occurs despite the agency's rhetoric to the contrary.

Rationing the amount of environmental data that is made available to the public is often a result of agency resource constraints, as well as the staff and computer time required to process data collected by the agency. For example, Toxic Release Inventory data, which is submitted annually to the EPA by thousands of facilities, is made available to the general public two years after it is reported because of the limitations of staff resources to process the data.
Environmental information is also rationed by routines and procedures that may extract a significant cost from the citizen. Environmental information traditionally has been available by contacting the regulatory agency directly by mail or by telephone. It is customary to require written requests for information, usually on a form provided by the agency. It is not uncommon that information offices levy a fee for data compilation, mailing, printing, or photocopying costs. Some information is available only in the agency's office, and often no photocopying is permitted. Information seekers must schedule an appointment to visit the office, travel to the office, wait until data is brought to a secured room, and then take notes from hundreds of pages of data. Thus, access to information, even for those who can pay for it in time or travel costs, is limited by the rules and regulations adopted by the organization.

Of course, the discretion of an agency employee may have a significant effect on information accessibility. Agency offices usually have a public information officer who is, in part, a gatekeeper, directing citizens to the appropriate staff person in the organization, or informing citizens what information is available and the procedures required for obtaining it. Often, citizens lack the knowledge of the regulatory system to ask questions that conform to the media-based divisions of the organization. Instead, their requests may take the form of a complaint that is generally articulated. The information officer who receives a complaint or request for information can easily tell the citizen that the information (as it has been framed by the citizen) is not available. Alternatively, the citizen may be overwhelmed with technical questions by an officer who ostensibly is seeking clarification. The citizen may give up because he or she does not understand the questions or the reasons for them. For citizens unfamiliar with the environmental regulatory system, or who distrust govemment agencies, these interactions may severely restrict their ability to obtain information.

An entirely different situation may exist when the information officer or agency technical staff member knows the citizen seeking information. Because of ongoing regulatory processes, agencies and regulated facilities tend to have interorganizational and personal relationships. These relationships constitute a regulatory community that develops its own regulatory culture (Meidinger 1987) in which information flows more freely. Unfortunately, the broader community that is affected by the decisions reached during these processes often has no such relationship, either between organizations or between individuals within the organizations. Such relationships can be vital to breaking through the impersonal routines of Lipsky's street-level bureaucrats. 


\section{The Internet and Information Rationing}

As part of their provision of public information, federal and state government agencies are adopting Internet technologies that are changing the quantity and quality of data available. The EPA, for example, has committed itself to dispersing information using the Internet, and it has made a wide range of data and information about the agency and its programs available online. The Internet can, in theory, make greater amounts of information available. A Web page may be expected to alleviate many of Lipsky's discretionary costs imposed by staff: it does not have the ability to withhold information, and the time costs should, in theory, be less than an in-person visit. Internet-based information, however, does not rectify the monetary costs. Nor does it necessarily overcome the citizen's unfamiliarity with how the agency functions more than a traditional contact with a staff person. Placing information on the Internet acts as a rationing mechanism because access to the Internetrequires a computer and introduces the need for a whole new set of skills and knowledge for its use. The rationing problem is deeper, however.

As many agencies are making new information available on the Internet, they are also curtailing the availability of information through traditional mechanisms such as the telephone (Coder 1997), partly due to reductions in staffing resources. An information-access paradox is developing: as greater amounts of environmental information are made available over the Internet, a substantial portion of the population - those without access to computers and without good Internet skills - fall farther behind. This paradox of information access is an environmental justice concern because it tends to occur in communities that traditionally have been disadvantaged in access to technologies and disenfranchised in political participation as a result, in part, of public policy.

How is this information paradox manifested in low-income and minority communities? A search of both Internetbased literature and traditional outlets for scholarly research revealed many articles on the need to bring information technologies to inner-city, urban, poor, and low-income neighborhoods (Benton Foundation 1998). Recent U.S. federal studies of the use of computers in American households reveal significantly lower frequencies of computer possession and online access among central-city residents and among households with incomes under $\$ 25,000$. Among households with both of these characteristics, less than 10 percent have online service (NTIA 1997). Concerns persist that low-income, central-city residents have become an "information underclass" (Benton Foundation 1998).

\section{Programmatic Response: Overcoming the Paradox}

What are the necessary conditions that will facilitate improved access to and use of Internet-based environmental information for residents and org anizations in America's urban neighborhoods? The key is to increase the social capital for access, use, and generation so that communities can manage information for their own purposes.

Many obstacles exist that can prevent traditionally disenfranchised neighborhoods from accessing environmental information and using it effectively. These obstacles include uncertainty about what information is available or where to obtain it; lack of access to information technologies, infrastructure, and hardware; inadequate formal education and experience to understand the data; and absence of the skills needed to process data into knowledge, which is the basis for effective participation (Lee 1992; Sawicki and Craig 1996). Gaining physical access to Internet-based information is not enough to overcome the paradox of the Internet as an information rationing mechanism. The community in question must gain control of the management of information itself (Kweit and Kweit 1987; Kellogg 1999b). To do this, citizens must be able to identify problems, assess data needs, identify data sources, collect and analyze data to create useful information, deliver this information to the community, and engage community members in efforts to solve problems.

While realization of the ideal state is unlikely, the role of community-based organizations is critical in building social capital for Internet use and participation in environmental decision-making processes. Community-based organizations working in urban neighborhoods have historically played an important role in mobilizing resources and resident participation in housing, poverty, and commercial revitalization efforts. Community-based organizations today seek to address environmental and environmental health problems in their neighborhoods (Heiman 1997; Kellogg 1999a; NAPA 2001). Community-based organizations with training and resources could provide a contact point, act as translators of environmental information to enhance community knowledge base, train residents to use the Internet, and organize participation in environmental problem solving. Without enhanced social capital, new information technologies will be underutilized, and therefore less inclusive of traditionally disenfranchised residents.

It is unlikely, however that community-based organizations and community leaders who have little experience in navigating environmental regulatory processes will be able to build social capital alone. In studies completed in 19962000 , community-based organizations in seven metropolitan areas in Ohio and metropolitan areas in six other states 
indicated a need for technical assistance in their efforts to acquire information through the use of the Internet (Stoecker and Stuber 1997; Kellogg 2000). Here, the role of collaboration and partnerships can provide additional resources to begin this process and to reconfigure the expert systems involved in envirommental decision making. One such partnership has formed to address information access, use, and generation, including access to information using the Internet.

\section{Sustainable Cleveland Partnership: Design and Implementation}

\section{History and Underlying Principles}

The Sustainable Cleveland Partnership (SCP) grew out of a series of conversations among several environmental and community-based practitioners and researchers. These discussions led to recognition of similar interests and emphases on community-based information access and environmental justice issues among projects that were beginning in Cleveland. The SCP has evolved into a dynamic and unique partnership of approximately a dozen representatives from community-based service and development organizations, local and national environmental organizations, local, county, state, and federal planning and environmental regulatory agencies, and a local university. ${ }^{3}$

The partnership began meeting in early 1997 and developed a mission, vision statement, and a set of programmatic goals. It became clear that although many environmental problems - air pollution, pediatric lead poisoning, vacant lots and brownfields, and a lack of greenspaceexist in Cleveland's neighborhoods, residents participated infrequently in the decision-making processes that had shaped those conditions. Partners from neighborhood-based and social service organizations identified inadequate access to envirommental information resources and tools as the root cause of this lack of participation.

Over several months, the partners adopted an overall strategy whereby community-based organizations would serve as vehicles to enhance the use of computer-based information sources in the community. These organizations would participate in projects to develop information tools and resources to increase accessibility. The partners agreed the goal was to build capacity among community members, so that over time, the role of the SCP partners would shift from project development toward technical advising and facilitation of community-initiated activities. The partners also reached a consensus that the SCP process and products should be replicable and useful not only to Clevelanders, but to other communities. To that end, each partnership meeting was documented and the products that were created have been evaluated.
The partnership was also an opportunity to build relationships across traditional organizational and bureaucratic boundaries. As communication was enhanced between organizations and individuals, personal relationships were established and SCP partners and the participants from the target communities became part of the regulatory culture in Cleveland that is accepted as legitimate by agencies and the regulated community. Eventually, neighborhood organizations and residents would have the capacity to be "at the table" or "in the conversation" to begin redefining the expert systems that frame environmental decision-making processes that affected the community.

Four programmatic goals were adopted by the partners: (1) enhance the availability and relevance of envirommental information provided to urban neighborhoods by govermment agencies and nonprofit organizations; (2) improve the capacity of community leaders (residents and community organization staff) to use the Internet as an information-access tool; (3) improve the capacity to use environmental information among these community leaders, so that the information gained from the Internet or other sources would be put to use effectively to address environmental problems these leaders identified as priorities; and (4) facilitate new and enhanced working relationships among Cleveland's neighborhood-based organizations, regulatory agencies, and the environmental advocacy community. These goals have been sought through design and delivery of four interrelated projects over the last four years, which are described hereinafter.

\section{Environmental Health Action Guide (1997-98)}

The goal of enhancing the availability and relevance of environmental information provided by government agencies and nomprofit organizations for urban neighborhoods was addressed primarily through the development of an online Environmental Health Action Guide. Early in the process, the SCP organized a community meeting in one of the target neighborhoods to announce the formation of the partnership and to solicit information about the environmental health issues that concerned neighborhood leaders and residents. The partners subsequently reviewed many Internet sources of information on these issues and assessed the Web pages on the basis of their relevance to urban neighborhoods. Partners discovered that some of the identified issues were not well covered in existing Web pages, and many of the existing Web pages were designed for the experienced Internet user. The SCP decided to create a Web page on environmental health issues oriented toward action that urban residents could take to decrease their exposure risk. The specific topics were based on additional information collected through one-on-one surveys with neighborhood leaders. Each page on the Internet 
guide uses the same overall format: a scenario story, a series of questions and answers about the particular environmental health topic, suggestions for actions to reduce risks, and sources for additional information about the problem. ${ }^{4}$

The content and format were revised several times by the SCP partners in direct cooperation with the participants, who became members of the Sustainable Cleveland Leadership Team (see below). This ensured the information available through the guide was relevant and accessible to neighborhood residents and their community-based organizations. The guide was released in November 1998 on the Internet. Hard-copy versions were al so printed and distributed over the next two years through community institutions in Cleveland. More than 2,500 free copies of the Environmental Health Action Guide have been delivered to schools, churches, community groups, and at conferences and workshops through an extensive outreach program conducted by the SCP project staff.

\section{Sustainable Cleveland Leadership Team (1999 and 2000)}

The goal of improving the capacity of community leaders (residents and community organization staff) to address envirommental issues was accomplished through a series of workshops held in four neighborhoods ${ }^{5}$ in the city of Cleveland. Two sessions of the leadership training were delivered approximately one year apart. The workshops were designed to improve use of the Internet as an access tool and to improve the information-use capacity for solving or mitigating environmental problems. The objective was to create a cadre of environmental leaders (the Sustainable Cleveland Leadership Team) from the target neighborhoods who could then assist other organizations and residents in their community in addressing environmental health concerns.

The content and structure of the workshops were based on three hypotheses: participants needed significant handson time using the Internet as an information-gathering tool; use of information available from the Internet would only be effective if the user had a broader understanding of the conditions and context in which information was generated and used; and, participants should come away from the workshops better able to address environmental problems in their communities in addition to gaining a broader understanding of substantive environmental health issues. ${ }^{6}$

Overall, participants worked through a process focused on problem-solving capacity. The workshop module topics included urban sustainability and environmental justice; a structured, seven-step problem-solving process; the information-management needs for problem solving, including a review of the major environmental laws and the regulatory framework that shapes the information that is available from public agencies; risk assessment as the basis of regulatory policies and priority setting; and processes to develop strategies for taking action. ${ }^{7}$ Each workshop lasted two to three hours. All of the modules used interactive exercises that either involved the leadership trainees in problem-solving exercises using a case study or concerns they had raised about their own neighborhoods, or involved them in searching for environmental information on the Internet. Each workshop also included a printed handbook (tools and additional hard-copy and Internet resources) for the participants to use once the training was completed.

The SCP graduated 18 environmental leaders in the first session in the spring of 1999 and trained an additional 14 leaders in the second session held in the spring of 2000. The trainees each received a certificate of recognition at the end of the process. Many of these graduates are now actively engaged in organizing participants in their communities for work on specific environmental health issues that have been identified since the training.

\section{Neighborhood Audit Profile (1999)}

The Neighborhood Audit Profile project in the summer of 1999 was designed to orient participants to the identification and collection of data specific to their neighborhood as a first step to environmental problem solving. Several leadership team graduates took part in the project, assisting in the training of their fellow neighborhood leaders. The project developed a profile of environmental attributes for the Lee-Harvard-Miles neighborhood in the southeast side of Cleveland. The profile was based on attributes identified with community leaders through several meetings. In two workshops, residents identified important sources of data about these attributes and collected some of the data using the Internet. The attributes included demographics, air pollution, Toxic Release Inventory facilities, contaminated land parcels, and the location of parks and open space. Project staff and student assistants created a GIS map to illustrate the location of these attributes. The maps generated considerable discussion among the participants, which led to discovery of a problem that is now under investigation by neighborhood leaders (see below). The results of the workshops were assembled into a handbook and delivered back to the participants. The project handbook provides step-by-step instructions for retrieving Internet-based environmental data. ${ }^{9}$

\section{Risk Training (2001)}

New training modules that focus on environmental risk of toxic air pollutants have most recently been developed and delivered to neighborhood groups. Risk assessment and management is the dominant framework for environmental policy development and implementation today in 
the United States, and it drives many of the decisions that affect urban neighborhoods. The Sustainable Cleveland Leadership Team workshops included risk-management concepts and basic risk-assessment techniques. The latest workshop topics included the basics of air toxins, environmental justice and Title $\mathrm{V}$, environmental risk assessment, and good neighbor campaigns. ${ }^{10} \mathrm{~A}$ round of risk-oriented training in additional neighborhoods was delivered in 2002 .

\section{Project Outcomes and Conclusions}

The members of the SCP are convinced from the experience designing and implementing these projects that a multifaceted, integrated approach to the access and use of environmental information has built the strongest basis for overcoming the rationing effect of the shift to Internet-based environmental information. This approach sought to improve the relevance of information available, improve skills to use the technology, improve community knowledge of the environmental regulatory system and the kind of information that is available to residents, and enhance knowledge of the decision-making processes that shape environmental conditions in urban neighborhoods.

The development of the Web-based Environmental Health Action Guide and the distribution of a hard-copy format to dozens of organizations and hundreds of residents has enhanced the information materials available to Cleveland's neighborhoods. The Web site has received several thousand hits.

Access to a computer is a critical issue for many residents and community leaders in urban neighborhoods (Benton Foundation 1998). The Internet-intensive workshops were held at the university computer lab. A few of the Sustainable Cleveland Leadership Team participants had computers in their homes or at work, but most used computers available at their neighborhood public library or recreation center. Cleveland is fortunate to have a relatively well-developed system for public access to the Internet at these locations. Participants in the workshop trainings exhibited significant improved capacity for using the Intemet. Many participants had not previously used the Internet, and by the end of the workshops they were accessing information about their own neighborhood through the EPA's Envirofacts Warehouse and EnviroMapper sites and the Environmental Defense SCORECARD. ${ }^{11}$ Participants viewed the Internet as one of the most effective mechanisms to allow them to influence environmental decision-making processes in their communities. These new or improved skills have begun to overcome many of the aspects of the Internet technology paradox.

The leadership team graduates have demonstrated an improved capacity for using information to address prob- lems, both because of their enhanced understanding of environmental issues and of how information is generated and used in decision making. During the neighborhood mapping process for the 1999 Neighborhood Audit Profile project, participants discovered that a cul-de-sac of townhouses was located on a site they knew had been an auto junky ard in the past. The site was investigated using Internet resources, and the leadership team and project nembers discovered it in fact had been designated a "potentially hazardous waste site" in the Ohio EPA's master sites list, receiving a "low-priority" status. Neighborhood leaders are concerned, however. The Lee-Seville-Miles Citizens Council, well-represented among the workshop participants, has initiated a local health survey for residents of the townhouses. The SCP partnership is assisting with volunteers to help the council conduct the survey.

Members of a community-based organization in the St. Clair-Superior neighborhood, also well represented on the leadership team, have made an environmental justice petition to the Ohio EPA regarding a draft air pollution permit (Title V) application by an electric utility company. The company seeks to start up some old generation units that had been grandfathered under the Clean Air Act amendments. These units, however, are several times more polluting than those with new source-pollution controls. Neighborhood residents and leaders, some of whom were the first graduates of the leadership team, are concemed about increased air pollution in a community that is already burdened with environmental and health problems. The group meets regularly with Ohio EPA staff (one of whom is an SCP partner) to address these concerns.

The various projects of the SCP have fostered networking and collaboration among divergent groups in Cleveland. Our efforts to identify and create new community assets, including community-based sources of information and existing knowledge about problem solving, have been shared among diverse community sectors - environmental, community development, service, and health. The work on the projects has also begun to build new relationships between the regional offices of state and federal regulatory agencies and several neighborhood and citywide organizations which traditionally have not focused on environmental problems. These organizations have begun making connections between healthy communities, sustainable communities, community development, and environmental issues. This has been one of the most interesting outcomes of the SCP.

SCP efforts have proven replicable. The Sustainable Washington Alliance has developed an Environmental Health Action Guide using the SCP. Internet guide as a model. ${ }^{12}$ A new partnership of university and communitybased organizations in Buffalo, New York, met with SCP members seeking guidance on the SCP's experiences. The 
group in Buffalo plans to create a similar partnership to address environmental justice issues; documentation of the work of the partnership proved critical to this effort as well.

The SCP project has gained regional and national recognition, a testament to both its approach and its unique mix of partners. Nationally, the project received a Certificate of Environmental Achievement from Renew America, a nomprofit organization that began by working closely with the President's Council on Sustainable Development (PCSD) during the Clinton administration. ${ }^{13}$ Two partners presented the project, upon invitation, at the National Town Meeting for a Sustainable America sponsored by PCSD in May 1999. In October 1999, the SCP was invited to present at the National Environmental Health Association's RightTo-Know conference. The project director has been invited to present at several regional and national EPA training and educational conferences as well.

While the Sustainable Cleveland Partnership has achieved many successes, several challenges have proven difficult, but it is hoped they will be resolved over time. A deeper issue regarding information accessibility remains unresolved. The partners had hoped to initiate change in the information providers as well as community members, stimulating the agencies involved in the partnership to change information dissemination methods to be more accessible. There has been some response to our suggestions that the agency Web pages are often too complicated for the average neighborhood leader to navigate. The trainees managed to use them, but the design of the Web pages needs to go further to make them accessible to the greatest extent possible.

Are the regulatory agencies more amenable to citizen participation? The individuals directly involved in the partnership projects have communicated willingly with neighborhood organizations and residents on environmental issues. The regional (Chicago) and central (Washington, DC) EPA offices have received reports on the workshops, have reviewed a training manual assembled after the second session of workshops, and are sharing these products with other EPA regions. We believe this demonstrates a genuine interest in enhanced community participation in environmental decision making in urban neighborhoods.

The overall results of the SCP project will not become fully known for several more years as the project expands into more Cleveland neighborhoods. An overall long-term goal was to change the role of the SCP itself, so that the partnership would become a source for technical assistance rather than an organizer of activities. As the Sustainable Cleveland Leadership Team graduates have developed their skills, the SCP has been able to begin this new role to some extent. The partners expect that the partnership between public agencies, nonprofit organizations, and community residents will grow and change, offering new opportuni- ties for building capacity in Cleveland's neighborhoods. For the long-term, the SCP envisions a cadre of community environmental leaders with the capacity to take a leading role in efforts to generate local data that reflects local concerns and needs, and use the Internet to make that data available to other neighborhood organizations and local environmental health organizations. When this stage is reached, the SCP will have fulfilled its mission and the Internet will no longer be a rationing mechanism for these urban residents.

\section{Acknowledgments}

The authors are grateful to the members of the Sustainable Cleveland Partnership for their help and encouragement. The activities described in this article were supported by grants from the Environmental Protection Agency's Environmental Justice Small Grants Program (\#EQ97512301) and the Cleveland Foundation, and by a faculty fellowship funded by the EPA from the Program for Risk Analysis, Center for Environmental Science, Technology and Policy, at Cleveland State University. 


\section{Notes}

1. This aspect of the federal policy responds to a series of citizen protests in the 1980 s over siting hazardous waste landfills in the Southeast and a series of studies done by the United Church of Christ Commission on Racial Justice, the U.S. General Accounting Office, and the Agency for Toxic Substances and Disease Registry. The studies documented a pattern of disproportionate impact and less effective enforcement of environmental regulations in low-income and minority communities for the siting of hazardous landfills and the cleanup of contaminated properties and buildings (GAO 1983; UCC 1987; ATSDR 1988).

2. The Clean Air Act $(1970,1977,1990)$ was designed to address air pollution from vehicles, industrial processes, fuel combustion in stationary sources, and solid waste disposal. Data to assess air quality is gathered from monitoring stations and from air pollution discharge permits issued to stationary pollution sources.

The Clean Water Act $(1972,1987)$ is the primary federal law that protects our nation's waters, including lakes, rivers, aquifers, and coastal areas. Under the act, each facility that discharges pollution into surface water (a point source) is granted a "permit to discharge" and is required to monitor the level of contaminants in its discharges and report to the EPA. This reporting has resulted in a database of the facilities that have permits and information about what they discharge. To assess surface water quality as it is affected by non-point-source pollution (runoff from streets, storm sewers, and land), the EPA, in partnership with state and local authorities, maintains water quality monitoring stations throughout each region and conducts on-site tests for certain pollutants.

The Safe Drinking Water Act $(1974,1986)$ requires the EPA to develop and enforce a set of national drinking water quality standards to safeguard public health. Each local, publicly owned water system must conduct regular testing to ensure the water it delivers in public water pipes meets national drinking water standards.

The Toxic Substances ControlAct (1972) established a system to identify and appraise the effects of existing and new substances - particularly synthetic chemicals - on human health and the environment. Data are generated through laboratory research on the effects of chemicals on biological organisms (see http://www.atsdr.cdc.gov/).

The Resource Conservation Recovery Act (1986) is the nation's primary law for governing solid and hazardous wastes, most of which are industrial or commercial wastes with the following characteristics: ignitability, corrosivity, reactivity, or toxicity. This act requires facilities that generate and manage hazardous waste to report on these activities to regulatory agencies. The data are compiled into the Resource Conservation Recovery Information System, available at http://www.epa.gov/enviro/html/rcris/roris_query_ java.html.
The Comprehensive Emergency Response, Compensation and Liability Act of 1980 and the Superfund Amendments and Reauthorization Act of 1986 address land contaminated by hazardous waste. Sites that pose the greatest threat to public health, safety, and the environment are placed on the National Priorities List and receive the highest cleanup priority. Under this legislation, the EPA is responsible for inventorying and tracking hazardous waste sites using the Comprehensive Environmental Response, Compensation and Liability Information System. In the United States, more than 35,000 sites exist in this database (available at http:// www.epa.gov/enviro/html/cerclis/cerclis_query.html).

The primary purpose of the Emergency Planning Community Right to Know Act of 1986 (Superfund Amendments and Reauthorization Act, Title III) is to inform communities and citizens of chemical hazards in their areas. The law requires businesses to report the locations and quantities of chemicals stored on-site to state and local governments so that communities can prepare to respond to chemical spills and similar emergencies. Local Emergency Planning Committees develop evacuation plans for residents and businesses near facilities that store hazardous and extremely hazardous materials on-site. It requires the formation of a Toxic Release Inventory compiled from report releases of more than 600 designated toxic chemicals to the environment submitted each year by polluting facilities to the EPA and state governments. The EPA compiles these data in an online, publicly accessible national computerized Toxic Release Inventory. The EPA's Envirofacts Warehouse (available at http://www.epa.gov/envirolindex java.html), is a searchable database that includes most data generated from air and water discharge permits, including the Toxic Release Inventory.

The Pollution Prevention Act (1999) focuses industry, government, and public attention on reducing the amount of pollution generated during manufacturing processes. The law encourages industries to implement cost-effective changes in production and operation to change the raw materials used, to increase efficiency in the use of energy, water, or other natural resources, and to adopt conservation practices. Pollution-prevention data are collected as part of the facility's report to the Toxic Release Inventory.

3. The SCP includes the following organizations: local environmental advocacy organizations (Earth Day Coalition, Environmental Health Watch); national environmental organizations (Environmental Defense, Pollution Prevention Alliance); local government (Cuyahoga County Planning Commission, City of Cleveland Division of Air Pollution Control); local nonprofit, social service-oriented organizations (Center for Families and Children, Neighborhood Centers Association); neighborhood-based organizations (St. Clair-Superior Neighborhood Development Association, Lee-Seville-Miles Citizens Council); environmental regulatory agencies (Ohio EPA Northeast District Office, EPA Regional Office in Chicago, EPA Cleveland Office); and a 
local university (Levin College of Urban Affairs at Cleveland State University). The work of the partnership is coordinated and staffed by the Earth Day Coalition.

4. The SCP Environmental Health Action Guide is available at http://www.nhlink.net/envirolscp.

5. The four neighborhoods were chosen because they had one or more of the following characteristics: low income, greater than 50 percent African American population, existing community-based organizations from which to draw participants, and a response from leaders in the neighborhood to our initial community outreach.

6. The design and delivery of the training modules was accomplished by a second group of partners, which included the authors, a staff member from Environmental Defense, and staff at the EPA's district office in Cleveland. Local practitioners in environmental departments presented information about local conditions. We relied extensively on existing Internet-based information in the workshop content to test the relevance and accessibility of that information to neighborhood leaders.

7. Several of the workshop modules are available online at http:/ /urban.csuohio.edu/ wendy/courses/scpmods.html.

8. Funding for the Leadership Training sessions came from the Cleveland Foundation and the EPA; undergraduate environmental and urban studies students from Cleveland State University assisted the partners in retrieving background information for the workshops and assisted participants on the computers during the workshop sessions.

9. The Neighborhood Audit Profile project was funded by Environmental Defense through the Pollution Prevention Alliance, the Cleveland Foundation, and the George Gund Foun- dation in Cleveland. The project was organized by the authors and an undergraduate student intern from BaldwinWallace College, with assistance from undergraduate students from the Levin College of Urban Affairs, Cleveland State University. A project in a second neighborhood was recently completed.

10. Funding for these workshops was given by the EPA through the Program in Risk Analysis at the Center for Environmental Science, Technology and Policy at Cleveland State University; the workshop on good neighbor campaigns was given in cooperation with Ohio Citizen Action.

11. The EPA's Envirofacts Warehouse is available at http:// www.epa.gov/envirolindex java.html; Environmental Defense's SCORECARD is available at http://www. scorecard.org.

12. Available at http://www.swampnet.org/swehag/. From the Sustainable Washington Environmental Health Action Guide, "Acknowledgments. First and foremost, this guide was inspired by the Sustainable Cleveland Environmental Health Action Guide. We thank the Earth Day Coalition and the Sustainable Cleveland Partnership for their leadership in creating a national model through which citizens and residents can become empowered to improve their health and the health of their homes, neighborhoods, and natural environment. With their permission, parts of their guide have been reproduced within this guide, for which we are extremely grateful."

13. The Bush administration has eliminated the President's Council on Sustainable Development Web page from the White House page. It appears the council has been disbanded. A search of White House Web page archives was unsuccessful in locating council materials.

\section{References}

Agency for Toxic Substances and Disease Registry (ATSDR). 1988. The Nature and Extent of Lead Poisoning in Children in the United States: A Report to Congress. Washington, DC: U.S. Department of Health and Human Services, Division of Public Health Service.

Benton Foundation. 1998. Losing Ground Bit by Bit. Available at http://www.benton.org/Library/Low-Income. Accessed February 2002.

Bullard, Robert, and Beverly Wright. 1992. The Quest for Environmental Equity: Mobilizing the African-American Community for Social Change. In American Environmentalism: The U.S. Environmental Movement, 1970-1990, edited by Riley Dunlap and Angela Mertig, 39-49. Philadelphia, PA: Taylor and Francis.

Castells, Manuel. 1989. The Informational City: Information Technology, Economic Restructuring, and the Urban-Regional Process. Oxford: Basil Blackwell.

Clinton, William Jefferson. 1994. Executive Order 12898. Available at http://www.epa.gov/compliance/resources/policies/ej/ exec order 12898.pdf. Accessed January 15, 2002.
Coder, George. 1997. EPA Information Officer. Personal conversation.

Desario, Jack, and Stuart Langton. 1987. Citizen Participation and Technocracy. In Citizen Participation in Public Decision Making, edited by Jack Desario and Stuart Langton, 3-17. Westport, CT: Greenwood Press.

Fischer, Frank. 1990. Technocracy and the Politics of Expertise. Newbury Park, CA: Sage Publications.

2000. Citizens, Experts and the Environment: The Politics of Local Knowledge. Durham, NC: Duke University Press.

Fitzpatrick, Kevin, and Mark LaGory. 2000. Unhealthy Places: The Ecology of Risk in the Urban Landscape. New York: Routledge.

Forester, John. 1989. Planning in the Face of Power. Berkeley, CA: University of California Press.

Giddens, Anthony. 1990. Consequences of Modernity. London: Polity Press.

Goldman, Benjamin. 1991. The Truth about Where You Live. New York: Times Books. 
Heiman, Michael. 1997. Science by the People: Grassroots Environmental Monitoring and the Debate over Scientific Expertise Journal of Planning Education andResearch 16(4); $291-99$

Kellogg, Wendy. 1998. Adopting an Ecosystem Approach; Local Variability in Remedial Action Planning. Society and Natural Resources 11(5): 465-83.

. 1999a. From the Field: Observations on Using GIS to Develop a Neighborhood Environmental Information System for Community-Based Organizations. Jonmal of the Urban and Regional Information Systems Association 11(1): 15-32. 1999b. Community-Based Organizations and Neighborhood Environmental Problem-Solving: A Framework for Adoption of Information Technologies. Journal of Environmental Planning and Management 42(4); 445-69.

2000. Community-Based Organizations and Information Technologies: A Comparison of Adoption in Six States. Presented at the Association of Collegiate Schools of Planning Anmual Conference, November 2, Atlanta, GA.

Kunreuther, Howard, and Paul Slovic. 1996. Science, Values and Risk. Amals of the American Academy of Political and Social Science 545: 116-25.

Kweit, Mary, and Robert Kweit. 1987. The Politics of Policy Analysis: The Role of Citizen Participation in Analytic Decision Making. In Citizen Participation in Public Decision Making, edited by Jack DeSario and Stuart Langton, 19-37. Westport, CT: Greenwood Press.

Landre, Betsy, and Barbara Knuth. 1993. Success of Citizen Advisory Committees in Consensus-Based Water Resources Planning in the Great Lakes Basin. Society and Natural Resources $6(3): 229-57$

Lee, Charles. 1992. Toxic Waste and Race in the United States. In Race and the Incidence of Environmental Hazards, edited by Bunyan Bryant and Paul Mohai, 10-27. Boulder, CO: Westview Press.

Leiss, William. 1990. Under Technology's Thumb. Montreal, Canada: Queen's University Press.

Lipsky, Michael. 1980. The Rationing of Services in Street-Level Bureaucracies. In Critical Studies in Organization and Bureaucracy, edited by F. Fischer and C. Sirianni, 213-30. Philadelphia, PA: Temple University Press.

Meidinger, Errol. 1987. Regulatory Culture: A Theoretical Outline. Law and Policy 9(4):355-86.

Naisbitt, John. 1994. Global Paradox: The Bigger the World Economy, the More Powerful Its Smallest Players. New York: Avon Books.

National Academy of Public Administration (NAPA). 2001. Ervironmental Justice in EPA Permitting: Reducing Pollution in High-Risk Communities is Integrat to the Agency's Mission. Report for the U.S. Environmental Protection Agency. Washington, DC: NAPA.

National Telecommunications and Information Administration (NTIA). 1997. Falling through the Net II: New Data on the Digital Divide. Washington, DC, U.S. Department of Commerce. Available at http.//www.ntia.doc.govintiahome/net2. Accessed January 2002.
Ramasubramanian, L. 1995. Building Communities: GIS and Participatory Decision Making. Journal of Urban Technology 3(1): 67-79.

Sawicki, David, and William Craig. 1996. The Democratization of Data: Bridging the Gap for Community Groups. Joumal of the American Planning Association 62(4): 512-23.

Shprentz, D. 1996. Breathtaking: Premature Mortality Due to Pariculate Air Pollution in 239 American Cities. Washington, DC: National Resources Defense Council.

Shutkin, William. 2000. The Land That Could Be: Environnentalism and Democracy in the Twenty-First Century. Cambridge, MA: MIT Press.

Stoecker, Randy, and Angela Stuber. 1997. Limited Access: The Information Superhighway and Ohio's Neighborhood-Based Organizations. Computers in Human Services 14(1): 39-56.

Susskind, Lawrence, and Jeffrey Cruikshank. 1987. Breaking the Impasse. New York: Basic Books.

Tauxe, C. 1995. Marginalizing Public Participation in Local Planning: An Ethmographic Account. Joumal of the American Planning Association 61(4): 471-81.

United Church of Christ (UCC). 1987. Toxic Waste and Race in the United States. New York: UCC, Commission for Racial Justice.

- 1994. Toxic Waste and Race Revisited: An Update of the 1987 Report on the Racial and Socioeconomic Characteristics of Communities with Hazardous Waste Sites. New York: UCC, Commission for Racial Justice.

U.S. Environmental Protection Agency (EPA). 1998. Final Guidance for Incorporating Environmental Justice Concerns in USEPA's NEPA Compliance Analyses. Washington, DC: Office of Environmental Justice.

1999. Environmental Justice Biennial Report: Moving Towards Collaborative Problem-Solving. Washington, DC: Office of Environmental Justice.

- 2002. What is Empact? Available at http $/ /$ www.epa.gov/ empact.about.htm. Accessed February 2002.

U.S. General Accounting Office (GAO). 1983. Siting of Hazardous Waste Landflls and Their Correlation with Racial and Economic Status of Surrounding Communities. Washington, DC: GAO. 